\title{
INDIAN OIL AND GAS: CONTROL, REGULATIONS AND RESPONSIBILITIES
}

\author{
C.A. WEBB*
}

\begin{abstract}
This paper is a brief review of the principles and issues related to the ownership, control and regulation of the exploitation of oil and gas resources located on Indian reserves in Canada. It will include a summary of relevant portions of the Indian Act, a summary of the context and content of the Indian Oil and Gas Act and Regulations, a summary of the proposed amendments to the Regulations, a brief discussion of the issue of selfgovernment related to this context and a discussion of the concept of the fiduciary responsibility of the Federal Government.
\end{abstract}

\section{INDIAN ACT}

This statute ${ }^{1}$ is the primary source of the statutory rules which govern and shape the relationship of the Indian people with the other levels of government in Canada. The composition of bands, the transfer of interests in land, descent of property, the management of lands, the management of Indian monies, the method of election of Chiefs and Band Councils, the powers of Band Councils and exemption from taxation are among the matters covered by this Act.

For the purposes of this discussion, two definitions in section 2 of the Act play a key role. The word "reserve" means "a tract of land, the legal title to which is vested in Her Majesty, that has been set apart by Her Majesty for the use and benefit of a Band", and the words "surrendered lands" mean "a reserve or part of a reserve or any interest therein, the legal title to which remains vested in Her Majesty, that has been released or surrendered by the Band for whose use and benefit it was set apart".

In the context of an oil or gas development on a reserve, it is necessary for the Band to release or surrender its interest to the extent necessary to enable Her Majesty to enter into the leases and the surface rights contracts which are necessary for the development.

Surrenders are governed by sections 37 through 41 of the Indian Act. A surrender under the Act is not a surrender in the usual conveyancing sense. Individual Indians or Bands cannot lease or convey reserve land, as this must be done by Her Majesty. A surrender for the purpose of granting an oil and gas lease and the incidental surface rights would be a conditional surrender. The land continues to be "lands reserved for Indians" as described in section 91(24) of the Constitution Act, ${ }^{2}$ and the Federal Parliament retains the exclusive legislative jurisdiction.

Most of the existing oil and gas developments on Indian reserves in Western Canada have been based upon a general surrender covering substantially all of the lands in a particular reserve.

Once the Band, by a surrender, has given the Crown the necessary authority to proceed with the exploration and development of oil and gas resources on a reserve, then the Crown enters into contracts in the form of

- Solicitor, Department of Indian Affairs and Northern Development, Ottawa, Ontario.

1. Indian Act, R.S.C. 1970, c. I-6 as am.

2. The Constitution Act, 1867, enacted by The Constitution Act, 1982, Schedule B to The Canada Act, 1982 (U.K.) 1982, c. 11. 
permits and leases with oil companies. The parties to the contracts are the Crown and the company.

As non-renewable assets, oil and gas resources are considered as part of the capital assets of the reserve and any revenues from their sale in the form of bonus and royalties are treated under the Indian Act as capital monies. ${ }^{3}$ Per acre rentals and surface rentals are treated as revenue monies.

The importance of the distinction between capital and revenue monies becomes clear if you examine sections 61 through 69 of the Indian Act which deal with the management of Indian monies. Under section 69 of the Act, the Governor in Council may permit a Band to control, manage and expand its revenue monies. Many Bands have, in fact, obtained this authority.

In contrast, the expenditure of capital monies of a Band requires the authorization of the Minister and the expenditure is limited to the purposes outlined in sections 64 and 65 of the Act. A difficulty arises in the area of the authorization of an expenditure of capital monies by a Band offreserve, as the sections were drafted at a time when it was probably not contemplated that Bands would want to purchase other lands, make investments in corporations and generally utilize their capital monies in investments not located on a reserve.

As already stated, royalties are capital monies, but Bands have tended, in general, to distribute on a per capita basis fifty percent of those revenues as they are received. This is permitted under paragraph 64(1)(a) of the Act and these revenues have provided a substantial source of income to individual Band members during the oil and gas boom. Of course, the oil and gas revenues are now substantially reduced and the per capita payments have had to be proportionately reduced. This has caused problems for individual Band members who had come to depend on this income.

The issue of the legal capacity of a Band is a difficult one in the context of economic development projects on a reserve. Courts have found that a Band is neither a natural person nor a corporation and due to this lack of status, a Band cannot acquire or hold real property, although it does have certain powers under the Indian Act regarding the use and occupation of reserve lands. ${ }^{4}$ This lack of status creates a great many problems when a Band wants to enter into a contractual relationship, particularly when you consider the added burden that there are severe limitations on the kinds of security which can be given by a Band.

To illustrate some of the difficulties, let us suppose that a Band wants to develop oil or gas resources on its own reserve and wishes to organize itself for that purpose. At the moment, the only reasonably practical solution is for the Band to form a corporation with shareholders and to enter into a contractual arrangement with Her Majesty to obtain the necessary rights. A disadvantage of this type of organization is that the corporation is subject to income tax, whereas the Band or an individual Band member are not taxable with regard to income earned on a reserve. Also, this form does

3. Supra n. 1 at s. 62.

4. Afton Band of Indians v. A.G.N.S. (1978) 85 D.L.R. (3d) 454 (N.S.S.C.); R. v. Cochrane [1977] 3 W.W.R. 660 (Man. Co. Ct.). 
not take account of the fact that many Band members want to relate to business conducted for their benefit on reserve as a Band member and not as a shareholder. Finally, the assets of such a corporation may be subject to attachment, whereas the personal property of a Band situated on a reserve is not subject to attachment.

\section{INDIAN OIL AND GAS ACT AND REGULATIONS}

\section{A. INDIAN OIL AND GAS ACT}

In the late 1960's and early 1970's, it was recognized that the 1966 version of the Regulations needed to be updated. As well, some leases were coming to the end of their primary term in February 1974 and the Crown wanted to have new royalty rates and regulations in effect prior to that date.

A Committee was formed to review the existing Regulations and to make recommendations for changes, particularly with respect to the greater involvement of Band Councils, the length of terms of leases, terms of renewal, methods of disposal, surface rights, rates of rental and rates of royalty.

During late 1973 and early 1974, the price of oil and natural gas rose rapidly. With the existing low, fixed royalty rates, the companies would have gained most of the benefits of the increase in prices. Therefore, all of the provinces passed statutes to cancel previous royalty rates and to establish new higher rates which also automatically increased proportionately with further price increases. Similarly, it was necessary for the Federal Government to find some method of increasing the royalties on Indian reserves to at least match the provincial rates.

An attempt was made by the Department of Indian Affairs and Northern Development ("DIAND") to solve the problem by amending the Regulations to allow the Minister to set royalties from time to time by prescription and applying these rates immediately to all existing leases. Such a prescription was issued in early 1974 , dramatically increasing the royalty rates. The oil companies maintained that this was illegal and threatened litigation over the matter. The Federal Government decided that an amendment to the Indian Act would be necessary in order to put the increases into effect.

As the Federal Government had previously promised that the Indian Act would not be amended without the Indian people being properly consulted and being fully in agreement, it was decided to take the management of Indian oil and gas resources out of the Indian Act and to put it into a separate Oil and Gas Act which was enacted on December 20, 1974.

The Indian Oil and Gas Act ${ }^{5}$ itself was very short and contained the following elements:

1. it legalized the royalty rates previously set by Ministerial Prescription;

2. it brought all existing oil and gas contracts under the new Act and the existing Oil and Gas Regulations; 
3. it provided for a new set of Regulations to be issued at a later date; and

4. it required the Minister to consult with Indian people in administering the Act.

\section{B. INDIAN OIL AND GAS REGULATIONS}

Following the passage of the Indian Oil and Gas Act, DIAND turned to the preparation of the new Indian Oil and Gas Regulations, which were finally put into force on April 21, 1977.6

Some of the important features of the Regulations which may differ from comparable provincial legislation may be summarized as follows.

Section 4 of the Regulations states that any disposition under the Regulations is subject to the applicable provisions of the Indian Act, the terms and conditions specified in the contract, the Indian Oil and Gas Regulations, and the applicable provincial laws provided that the Minister has not otherwise directed in writing. It was necessary to make provincial laws applicable as there are few satisfactory federal laws in this area. By allowing the Minister to make directions, it was felt that this would allow corrective action in the event that a particular provincial law might be declared inapplicable by the Courts or in the event that a Province passed a new law which would be detrimental to the development of oil and gas resources on Indian reserves.

Permission to conduct exploratory work on a reserve is obtained in the form of an exploratory licence obtained under section 5 . The applicant may or may not have a permit or a lease. A problem has arisen in this area with regard to data, as some Bands would like to receive copies of all data, so that they would be better informed about developments on their reserves.

Section 7 of the Regulations provides for the disposal of available oil and gas rights in Indian lands by the Manager, either by public tender or by a negotiated agreement. In either case, the approval of the Band Council concerned is necessary to set the terms and conditions under which the disposal will be made.

Over time, the length of the lease terms have been reduced from 21 years to 5 years. The leases are renewable where there is continuing production and under certain other specified conditions. This renewal is at the Manager's sole discretion.

With regard to surface rights, the Band or the surface occupant has the right to adequate compensation. However, there is no arbitration board for the determination of this compensation on Indian land.

Section 41 of the Regulations provides for an appeal to the Minister against any decision of the Manager or of any failure to make a decision. In drafting the Regulations, there was an attempt made to protect the Manager from being prevented from making decisions due to an inability to get a consent from a Band Council. In any event, there have been few appeals under this section.

6. C.R.C. 1978 , c. 963 , as am. SOR/81-340. 


\section{INDIAN OIL AND GAS TASK FORCE}

In April 1986, a workshop attended by Chiefs and representatives of oilproducing Bands in Canada was held in Edmonton with a view to determining whether or not changes were required to the Indian Oil and Gas Act and Regulations. As a result of this meeting, a Task force was established to study the issue and to report back to the Chiefs.

The Task Force included a majority of Indian members with representation from both DIAND and the Department of Justice. The Task Force had the following mandate:

1. to develop proposals for changes to Oil and Gas Act and Regulations;

2. to set out alternative frameworks for the achievement of Indian control of future resource management, including the role of the Indian Minerals West Office of DIAND; and

3. to participate in certain immediate decisions regarding the latter office, such as selection of a new full-time senior officer.

Other issues addressed by the Task Force included employment and training and financial incentives for industry to develop resources on Indian lands.

The major principle which emerged during these discussions was the desire of Indian people to control the disposal of oil and gas resources on their lands and to take an active part in the management and regulation of the exploitation of these assets and the resulting revenues.

Throughout its deliberations, the Task Force faced the fundamental issue of whether to develop proposals leading to complete and absolute control by the Bands, or to develop a transitory approach to control providing for immediate meaningful change but with a view to moving from the current system of Federal control to a system controlled by the Indian people.

Of course, some Bands want to move immediately to full Indian control of resources and other matters which they feel are within their jurisdiction, while other Bands are concerned about the costs and the risks of moving too quickly or in too extreme a fashion. Currently, the Federal Government makes a substantial economic and administrative commitment to Bands and many Bands are unwilling to alter this arrangement.

Ultimately, the Task Force members were able to consolidate their varying views into a common set of recommendations which were presented at a Chiefs' Assembly held in Edmonton, Alberta on March 5 and 6, 1987.

The Assembly supported the decision by DIAND to form a new body which will be called Indian Oil and Gas Canada to carry out the role of the Federal Government in oil and gas issues, and to substantially increase the budget and the number of staff which will be made available to this new organization. The Assembly also supported a recommendation to form an Indian Resource Council to perform an advisory role to this body.

The Assembly also approved the recommendation of the Task Force that, as an interim measure, the Regulations should be amended to more accurately reflect the existing policies of DIAND with regard to the 
disposal of oil and gas resources and to include some other changes of an operational nature which were felt to be necessary.

\section{AMENDMENTS TO THE REGULATIONS}

The major thrust of the proposed amendments is to change the focus of the decision-making authority from the Manager to the Band Council. Due to the various responsibilities of the Minister in these matters, it was not possible to give full decision-making authority to the Band Councils.

Therefore, throughout the proposed regulations, there are references to approval by the Band Council concerned, submission of information to the Band Council concerned, meeting with the Band Council concerned, obtaining signatures on leases from the Band Council concerned, consulting with the Band Council concerned and inspections by the Band Council concerned. Requirements of this nature have been added to virtually every section where, previously, the Manager had full authority to make decisions.

In reality, depending upon the level of sophistication and interest of the Band, the policy of DIAND has been to allow Bands and Band Councils to participate in oil and gas development in virtually the same manner as is being proposed in the amendments to the Regulations.

Additional flexibility has been included in the proposed amendments, by including a provision which would allow a Band Council to give the Manager the authority to act on its behalf if it wants to limit its participation in the decision-making process.

A second feature of the proposed amendments is an increase in the amount of information provided by companies and increased reporting requirements to the Band Council concerned and to the Manager.

The proposed amendments will be further developed in consultation with representatives from the oil and gas industry and the Indian Bands concerned.

The long-term goal is for full Indian control of oil and gas resources on reserves, and that will require changes to the Indian Act and the Indian Oil and Gas Act together with the development of oil and gas management expertise in the Indian community.

\section{FIDUCIARY RESPONSIBILITIES}

This section deals with the subject of the fiduciary responsibilities of the Minister and the Department of Indian Affairs in a general way, but attempts to relate that discussion to the subject of resource development on Indian reserves. It contains four parts:

- general definition of fiduciary relationship,

- how does this obligation arise in the context of the activities of DIAND?

- has Guerin ' resolved this issue?

- what are the implications for resource development on Indian reserves? 


\section{A. GENERAL DEFINITION OF FIDUCIARY RELATIONSHIP}

In terms of a general definition, Black's Law Dictionary contains the following statements under the heading "fiduciary relation":"

1. An expression, including both technical fiduciary relations and those informal relations, which exists whenever one man trusts and relies upon another.

2. It exists where there is special confidence reposed in one who in equity and good conscience is bound to act in good faith and with due regard to interests of the one reposing the confidence.

3. A relation subsisting between two persons in regard to a business, contract, or piece of property, or in regard to the general business or estate of one of them, of such a character that each must repose trust and confidence in the other and must exercise a corresponding degree of fairness and good faith.

Some examples of this type of relationship which give an idea of the range that can be covered under this general concept are: attorney and client, guardian and ward, principal and agent, executor and heir, trustee and beneficiary of a trust and landlord and tenant.

\section{B. HOW DOES THIS OBLIGATION ARISE IN THE CONTEXT OF DIAND'S ACTIVITIES?}

As can be seen from these examples, the range of relationships which fit within the general definition is very wide and each relationship and its corresponding obligations have been defined in most cases both by the common law and by statute.

The difficulty of applying this general concept to the work of resource development on Indian reserves is illustrated by the following statement from an unpublished paper co-authored in 1986 by W.R. McMurty and A. Pratt: 9

There can, in other words, be no single model of the fiduciary relationship between the Indian people and the Crown. There can, however, be a general theory of shifting emphasis along a continuum between the extremes of agency and trust, with presumptions to guide courts or negotiators as to the appropriate model in a given state of facts.

Mr. Justice Dickson in Guerin ${ }^{10}$ found that there was an obligation on the part of the Crown arising out of the general inalienability of Indian land except to the Crown which was transformed into a fiduciary obligation by the application of subsection 18(1) of the Indian Act, which requires the Crown to hold reserves for the use and benefit of the respective Bands, and by the application of the surrender provisions, which restrict alienation of reserves except in accordance with the provisions of the Act:"

I make no comment upon whether this description is broad enough to embrace all

fiduciary obligations. I do agree, however, that where by statute, agreement, or perhaps

by unilateral undertaking, one party has an obligation to act for the benefit of another,

8. Black's Law Dictionary (Revised 4th Ed., 1986) at 753 and 754.

9. W.R. McMurtry Q.C. and A. Pratt, "Indians and the Fiduciary Concept, Self-Government and the Constitution: Guerin in Perspective" unpublished, presented to the 1986 Annual Institute on Continuing Legal Education, Toronto, 6 February 1986 at 17.

10. Supra n. 7 at 383.

11. Id. at 384. 
and that obligation carries with it a discretionary power, the party thus empowered becomes a fiduciary. Equity will then supervise the relationship by holding him to the fiduciary's strict standard of conduct.

\section{McMurtry and Pratt present the following argument: ${ }^{12}$}

... All dealings between Indian people and the Crown are clothed with a fiduciary aspect, as the result of the Royal Proclamation [of 1763]. It is a declaration whose effects, like the Magna Carta, reverberate undiminished long after its immediate causes are gone. It must be kept in mind that in 1763 the British hold on our continent was tenuous, and the Indian nations were a significant force to be carefully dealt with. The "Frauds and Abuses" referred to in the Proclamation had led to "great Dissatisfaction" among the Indian people, and they were perfectly capable of expressing their dissatisfaction in open hostility, endangering the Imperial claim on the continent. The Proclamation may have been unilateral, but it resulted in the Indians accepting that protection by keeping the peace. To translate this into legal language used by Mr. Justice Dickson, the Indian people were induced by the promise of protection offered in the Royal Proclamation to alter their legal position. The promise cannot now be ignored to the Indians' detriment whenever their land interests are interfered with by the Crown. The principle is the same in the grand scheme as in the paradigm fact situation of the Musqueam surrender.

Likewise, the Indian treaties, particularly the treaties of the latter part of the 19th and early 20th century, which expressly deal with land surrenders directly to the Crown, are "agreements" concluded within the framework of the regime established in 1763. One recalls Mr. Justice Dickson's description of the creation of fiduciary relationships as including agreements and unilateral undertakings. Like the Musqueam surrender in the 1950's, the treaties were entered into at the instigation of the representatives of the Crown, based upon oral negotiations and assurances similar to those which Mr. Justice Dickson states "form the backdrop against which the Crown's conduct in discharging its fiduciary obligation must be measured". In non-treaty areas, unextinguished aboriginal rights to land are held within the protection of the same fiduciary relationship, albeit in an inchoate way. [foot-notes omitted]

McMurtry and Pratt also suggest that an obligation arising in this way could be extended to the political sphere by recognizing that the Crown holds attributes of Indian nations' sovereignty in trust. ${ }^{13}$

As the Worcester case suggests, the very act of treaty-making implies the recognition by each party that a self-governing nation is the party on the other side of the transaction. How, one wonders, can one consistently advocate the existence of a set of fiduciary obligations with self-government? The answer surely is in the acceptance of varying degrees of sovereignty combined with a notion of political trusteeship. Clearly, in 1763, the Indian nations which were subject to the Royal Proclamation, as suggested by Chief Justice Marshall in Johnson, had an impaired sovereignty, both by virtue of political dominance and by the Royal Proclamation's undertaking to protect the Indian nations from frauds and abuses. They were recognized as both "nations" and "subjects" without apparent inconsistency. The subsequent treaty-making activity was thus between a dominant Crown on the one hand and a "domestic dependent state" on the other. The treaties are compacts between self-governing nations, but who are unequal. The Crown, within its self-imposed duty of protection, continues to owe to the Indian people a duty to respect their self-governing nature and at the same time to protect them as long as the Indians are under the domination and simultaneous protection of the Crown. [foot-notes omitted]

McMurtry and Pratt also argue that the fiduciary duties of the Crown are owed by the executive branch of the Federal Government not because Parliament has created them but because of pre-existing law and policy.

In the context of resource development on Indian reserves, it can be said with certainty that a fiduciary obligation arises upon a surrender pursuant

12. Supra n. 9 at 11.

13. Id. at 11 and 12, referring to Worcester v. The State of Georgia (1832) 6 Peters 515 and Johnson and Graham's Lessees v. M'Intosh (1823) 8 Wheaton 543, both per Marshall, C.J.U.S. 
to the Indian Act, and Mr. Justice Dickson's judgment in Guerin could be interpreted to mean that this legal obligation does not arise until a surrender is made. Madame Justice Wilson seems to say that the fiduciary obligation pre-dates the surrender, as she states in her judgment: ${ }^{14}$

I think that when s. 18 mandates that reserves be held by the Crown for the use and benefit of the Bands for which they are set apart, this is more than just an administrative direction to the Crown. I think it is the acknowledgement of a historic reality, namely that Indian Bands have a beneficial interest in their reserves and that the Crown has a responsibility to protect that interest and to make sure that any purpose to which reserve land is put will not interfere with it.

If this view was accepted, it could be interpreted to mean that the Crown is under a positive obligation to actively promote, with Indian Bands, the highest and best use of all reserve lands even where the Band has not expressed any interest in a surrender, although Madame Justice Wilson does characterize this pre-surrender duty in negative terms as follows: "to protect and preserve the Bands' interests from invasion or destruction". ${ }^{15}$

\section{HAS GUERIN RESOLVED THIS ISSUE?}

It would perhaps be useful at this point to discuss the Guerin ${ }^{16}$ case in a general way, as the Supreme Court of Canada dealt with many difficult and uncertain issues in the native rights area in a very comprehensive fashion.

In that case, three separate but concurring judgments were delivered. There was a unanimous view that the Crown should pay damages for what happened, but there was considerable internal disagreement amongst the Justices respecting the proper legal basis of the Crown liability to the Band.

The majority judgment was delivered by Chief Justice Dickson and concurred in by three of the other Justices. This judgment is likely to be the approach that will govern future cases.

Madame Justice Wilson delivered a separate opinion which was concurred in by two Justices. This opinion contained a greater measure of moral indignation at the conduct of government of ficials than is exhibited in the majority opinion and concurred in the result determined by Chief Justice Dickson.

Mr. Justice Estey delivered his own separate opinion concurring in the result but resting his decision on a completely different legal basis.

This very brief summary of the decision should be sufficient to indicate that, even within the Supreme Court of Canada, there is considerable disagreement as to the proper application of the concept of fiduciary obligation to the relationship between the Crown and the Indian people. While the case is certainly a very significant signpost, it could not be considered to be the final word on this issue.

McMurty and Pratt conclude that: ${ }^{17}$

It must be kept in mind that in our view, the fiduciary relationship is a fluid and flexible one, and that the specific elements of the fiduciary duty will vary with time, with the relative sophistication of the Indian peoples involved and with many other factors. There

14. Supran. 7 at 349.

15. Id. at 350.

16. Supra n. 7.

17. Supra n. 9 at 20, referring to Simon v. The Queen [1985] 2 S.C.R. 387. 
will certainly be cases when the government should be judged as a pure trustee of the assets of people who are not accustomed to the dominant legal system. There will certainly be other cases where the government is little more than an agent self-appointed or appointed by Indian communities to fulfill the instructions of a competent and mature principal which happens to be Indian. In between, we cannot count the variations. $\mathrm{Mr}$. Justice Dickson has not attempted to define nor to limit it any more than he has attempted to fully define and limit the nature of aboriginal or Indian title, or in the Simon case to

define the nature in law of an Indian treaty.

\section{WHAT ARE THE IMPLICATIONS FOR RESOURCE DEVELOPMENT ON INDIAN RESERVES?}

This brings us to the question of the implications of all of this for resource development on Indian reserves.

Following from Guerin, ${ }^{18}$ it would seem that the discretion of the Crown under the Indian Act is narrowed by requiring that the disposition by the Crown must in fact be for the Band's benefit regardless of the Governor in Council's subjective view of the matter. The general standard against which the Crown's conduct will be judged would seem to involve two elements:

1. the best interests of the Band objectively determined; and

2. the wishes or objectives of the Band.

Obviously, DIAND may have a problem where these two standards are in conflict. In view of this and as a measure of self-protection, it may be that DIAND would want to do the following things in order to meet the standard:

1. keep a Band fully informed of any discussions between the Crown and third parties respecting development or investment proposals;

2. ensure that development opportunities are publicly advertised and tendered wherever possible;

3. obtain independent advice itself respecting the merits of development proposals;

4. encourage a Band to seek independent professional advice on proposed transactions;

5. ensure that proposals are fully discussed with and voted on by the Band, recognizing that Band Councils may object to this, but realizing that the Supreme Court has emphasized that the Crown's duty is to the Band as a whole;

6. ensure that, to the greatest extent possible, all documentation (for example, a written surrender) contains specific conditions which have been agreed to or discussed with the Band.

In summary, the concept of fidicuary obligation is an elusive one, but one that must be wrestled to the ground in each transaction involving Indian people and Indian lands. Hopefully, in the years to come, there will be more agreement and definition in terms of the application of the concept to these transactions, but, in the meantime, we must attempt to deal with it in as flexible and open a manner as possible.

18. Supra n. 7. 